\title{
ANALISIS KELAYAKAN EKONOMI \\ OBYEK WISATA PENYANGGA GEOPARK \\ DI KABUPATEN MERANGIN PROPINSI JAMBI
}

\author{
Radinal $^{1}$, Ishak ${ }^{2}$ \\ Prodi Teknik Sipil Universitas Muaro Bungo ${ }^{1}$, Prodi Teknik Sipil UMSB ${ }^{2}$ \\ ishakumsb@gmail.com ${ }^{2}$ \\ DOI: http://dx.doi.org/10.31869/rtj.v2i2.1439
}

\begin{abstract}
Abstrak: Pemerintah Kabupaten Merangin berupaya menjadikan sektor pariwisata sebagai salah satu andalan penggerak perekonomian wilayah. Peningkatan Situs Geopark menjadi target pemerintah Kabupaten Merangin, terdapat beberapa objek wisata yang dapat menunjang peningkatan status Geopark tersebut salah satunya objek wisata Danau Pauh yang terletak di Desa Danau Pauh Kec. Jangkat. Kendala yang dihadapi yaitu permasalahan kondisi sarana transportasi menuju objek wisata tersebut. Kondisi jalan dibeberapa tempat wisata yang kurang memadai seperti pada obyek wisata Danau Pauh, menjadi salah satu alasan utama kurangnya minat wisatawan. sehingga dibutuhkannya perbaikan dan pengembangan jaringan jalan.Perlu dilakukan peningkatan jalan menuju obyek wisata tersebut, namun apakah investasi tersebut memberikan hasil yang diharapkan, untuk itu perlu dikaji kelayakannya.

Kelayakan yang dianalisis terdiri dari biaya investasi dan manfaat yang diterima. Manfaat yang ditinjau terdiri dari manfaat langsung dan tidak langsung. Dari hasil analisis dapat dideskripsikan jalan tersebut merupakan jalan kabupaten dengan lalulintas rendah berdasarkan peraturan yang ada dapat direncanakan jalan tersebut dengan lebar badan jalan 5,5 m dengan panjang $1,03 \mathrm{~km}$ dengan lapis aspal. Berdasarkan analisis ekonomi yang dilakukan sesuai dengan kriteria investasi, dapat ditarik kesimpulan. NPV sebesar Rp. 78.647.373.948,72 menghasilkan nilai positif, maka investasi tersebut menghasilkan keuntungan(arus kas). Diperoleh tingkat pengembalian ekonomi internal EIRR sebesar 22,52 \%. Bahwa hasil EIRR diatas suku bunga, jadi investasi dapat dilaksanakan.
\end{abstract}

Kata Kunci: Kriteria Investasi, Manfaat Langsung, Manfaat Tidak Langsung

\section{PENDAHULUAN}

Keanekaragaman potensi wisata di Kabupaten Merangin salah satu yang menjadi fokus pemerintah yaitu peningkatan status Geopark. Pemerintah berupaya menjadikan sektor pariwisata sebagai salah satu andalan penggerak perekonomian. Dibeberapa tempat wisata memiliki jarak tempuh yang cukup panjang dan sering kali ditemui kondisi jalan menuju lokasi wisata yang kurang memadai, seperti pada obyek wisata Danau Pauh, menjadi salah satu alasan utama kurangnya minat wisatawan, sehingga dibutuhkannya pengembangan perbaikan jalan.

Berdasarkan pertimbangan kondisi alam serta aset wisata dan budaya yang dimiliki dan keanekaragaman potensi wisata di Kabupaten Merangin salah satu yang menjadi fokus pemerintah yaitu peningkatan status Geopark. Pemerintah Kabupaten Merangin berupaya menjadikan sektor pariwisata sebagai salah satu andalan penggerak perekonomian.Sementara kondisi aset wisata serta kondisi alam dan budaya yang ada di danau pauh sangat menunjang untuk menjadikan sektor pariwisata sebagai salah satu pendapatan asli daerah (PAD). Oleh karena itu sangat dibutuhkannya pembangunan dan peningkatan prasarana jaringan jalan menuju lokasi wisata obyek wisata Danau Pauh.

Untuk melakukan perbaikan jalan tersebut pemerintah daerah memerlukan investasi yang cukup besar. Agar supaya investasi yang akan digunakan dalam pelaksanaan pembangunan dan peningkatan jalan obyek wisata Danau Pauh maka perlu dilakukan analisis kelayakan ekonomi pembangunan dan peningkatan jalan menuju obyek wisata Danau Pauh.

1.1 Peranan Sistem Transportasi

Perananan sistem transportasi yang paling menonjol adalah untuk mendukung pengembangan wilayah atau pertumbuhan ekonomi suatu daerah. Dalam kaitan ini prasarana transportasi (jaringan jalan) merupakan suatu syarat perlu (necessary 
condition), meskipun bukan syarat cukup (sufficient condition) bagi ekonomi suatu daerah untuk berkembang (Lembaga Pengabdian Kepada Masyarakat Institut Teknologi Bandung, 1997 dalam Martin K., 2008).

Menurut jenis kegiatannya proyek transportasi dibedakan menjadi empat, yaitu pembangunan baru (new investment), perluasan proyek (project expansion), rehabilitasi, pemeliharaan (Lembaga Pengabdian Kepada Masyarakat Institut Teknologi Bandung, 1997 dalam Martin K., 2008).

1.2 Biaya

Biaya (cost) adalah semua pengorbanan yang dibutuhkan dalam rangka mencapai suatu tujuan yang diukur dengan nilai uang. Komponen biaya proyek didefenisikan sebagai komponen dampak yang mempunyai besaran kuantitatif yang negatif ataupun merupakan komponen dampak yang merugikan (Tamin $\mathrm{Z}$. O., 2008). Komponen manfaat proyek adalah komponen dampak yang mempunyai besaran positif atau secara harfiah merupakan komponen dampak yang terasa bermanfaat bagi pihak yang ditinjau. Komponen manfaat proyek yang sering diperhitungkan dalam suatu studi kelayakan proyek transportasi meliputi (Tamin Z. O., 2008): Vehicle operating cost saving, Travel time saving, Accident cost saving, Consumer-surplus, dan Producer-surplus.

1.3 Aspek Kelayakan

Tinjauan ekonomi dari suatu proyek transportasi berhubungan dengan upaya untuk menentukan apakah apakah proyek tersebut akan memberikan sumbangan atau mempunyai peranan positif dalam pembangunan ekonomi secara keseluruhan, dan apakah peranannya itu cukup besar untuk men-justifikasi penggunaan sumber-sumber langka yang dibutuhkan. Untuk dapat mengetahui lebih rinci tentang analisis kelayakan ekonomi, hal yang paling mudah dilakukan adalah dengan membandingkannya dengan analisis kelayakan finansial.

\section{METODE PENELITIAN}

\subsection{Pendekatan Penelitian}

Pada penelitian ini metode yang digunakan yaitu pendekatan metode kombinasi. Metode penelitian kombinasi merupakan pendekatan dalam penelitian yang kuantitatif dan kualitatif. Hal itu mencakup landasan filosofis, penggunaan pendekatan kualitatif dan kuantitatif, dan mengkombinasikan kedua pendekatan dalam penelitian, sehingga diperoleh data yang lebih komprehensif, valid, reliable dan obyektif.

2.2 Pengumpulan Data

Pengumpulan Data Tujuan Pertama Penelitian, meliputi Kajian Pustaka. Pengumpulan Data untuk Tujuan Kedua Penelitian, meliputi Kajian Pustaka dan Wawancara. Pengumpulan Data Tujuan Ketiga yaitu dengan menyimpulkan hasil data yang diperoleh dari tujuan satu dan dua.

2.3 Analisis Data

Analisis Data Tujuan Pertama menggunakan deskripsi alternatif skema. Keluaran dari analisa ini adalah berupa desain awal (basic design). Analisis Data Tujuan Kedua dengan Kuantifikasi komponen manfaat dan biaya yang signifikan dan estimasi. Hasil dari tahapan ini berupa tabulasi seluruh komponen manfaat dan biaya dalam besaran moneter. Analisis Data Tujuan Ketiga, upaya mencari ukuran penerimaan, penolakan dan pengurutan suatu proyek, digunakan kriteria investasi (investment criteria) dengan menggunakan perhitungan nilai sekarang (present value) dari arus benefit dan biaya selama umur proyek.

\section{HASIL DAN PEMBAHASAN}

Karakteristik atau spesifikasi jalan sebelum dan setelah dikembangkan yaitu : Kondisi eksisting pada penelitian ini panjang jalan $1,3 \mathrm{~km}$, dengan lebar jalan 5 meter, perkerasan menggunakan kelas c, kondisi jalan rusak, jalan merupakan jalan kabupaten, dengan lalulintas rendah dan jarak jalan obyek wisata ke pusat kabupaten sejauh $137 \mathrm{~km}$. Berdasarkan literatur dan observasi di lapangan jalan dapat dikembangkan berdasarkan peraturan tata cara perencanaan geometrik jalan antar kota, undang-undang No.38 tahun 2004 serta peraturan terkait didapat rencana pengembangan jalan dimana Lebar badan jalan $5,5 \mathrm{~m}$, bahu jalan $1 \mathrm{~m}$ kiri dan $1 \mathrm{~m}$ kanan, penambahan perkerasan kelas B dan kelas A dengan ketebalan minimum $15 \mathrm{~cm}$, serta menggunakan kelas $\mathrm{S} 1 \mathrm{~m}$.

Hasil identifikasi biaya dan manfaat dapat disimpulkan bahwa biaya yang dikeluarkan untuk investasi berdasarkan perbandingan Masterplan paleobotani dan standar harga satuan kabupaten tahun 2015.

\begin{tabular}{lr}
\hline 294 & Fakultas Teknik UMSB \\
& ISSN 2599-2081 \\
& EISSN 2599-2090
\end{tabular}


Biaya pengembangan jalan Rp. 7.640.068.000,00. Manfaat diambil dari Penghematan terhadap Biaya Operasional Kendaraan (BOK),Pendapatan Retribusi Obyek Wisata Danau Pauh dan Pendapatan Masyarakat disekitar Obyek wisata dengan total Rp. 66.648.652,70 pada tahun 2016.

Berdasarkan Evaluasi kelayakan proyek secara analisi ekonomi berdasarkan kriteria investasi di dapat :

1. Pada akhir periode analisis diperoleh selisih antara jumlah nilai bersih sekarang serta manfaat yang diterima. Hasil perhitungan NPV terhadap biaya yang dikeluarkan oleh Pemerintah

2. Daerah dan manfaat yang diterima selama investasi 20 tahun, diperoleh jumlah nilai bersih investasi (NPV) sebesar Rp. 127.530.021.309,01. NPV menghasilkan nilai positif.

3. Hasil dari perhitungan secara grafis tersebut, diperoleh tingkat pengembalian ekonomi internal EIRR sebesar 22,12\%. Bahwa hasil EIRR diatas suku bunga jadi investasi dapat dilaksanakan.

4. Metode Rasio Manfaat Biaya (Benefit Cost Ratio) yang dihasilkan 12,43. Nilai $\mathrm{B} / \mathrm{C}$ lebih dari 1 menunjukkan layak secara ekonomi

\section{PENUTUP}

Perlu adanya upaya untuk meningkatkan jumlah pengunjung melalui promosi, sehingga nantinya dapat menjadi salah satu potensi sumber penerimaan retribusi untuk meningkatkan pendapatan asli daerah. Pengembangan jaringan jalan ke lokasi obyek wisata di Kabupaten Merangin tetap harus dilaksanakan Karena Investasi ini pada awalnya akan mendorong pertumbuhan wilayah dan menjadi dasar untuk pengembangan kepariwisataan di Kabupaten Merangin. Sehingga di masa mendatang dapat menjadi salah satu andalan sumber penerimaan retribusi untuk meningkatkan pendapatan asli daerah.

Perlu dilakukan pengembangan jalan berdasarkan pada standar yang berlaku. Untuk penelitian lebih lanjut perlu dilakukan juga analisis finansial dan memperhitungkan faktor resiko ketidakpastian.
DAFTAR PUSTAKA

Badan Perencanaan Pembangunan Daerah Kabupaten Merangin, Rencana Tata Ruang Wilayah Kabupaten Merangin 2014, Merangin, 2014

Brigham, Eugene F., dan Houston, Joel F., Manajemen Keuangan Buku I, Edisi Kedelapan, Penerbit Erlangga, Jakarta, 2001

Departemen Pekerjaan Umum, Pd. T-15-2005-

B, Perhitungan biaya operasi kendaraan Bagian I : Biaya tidak tetap (Running Cost), Jakarta, 2005

Departemen Pekerjaan Umum, Pd. T-18-2005B, Pedoman Pra Studi Kelayakan Proyek Jalan dan Jembatan, Jakarta, 2005

Departemen Pekerjaan Umum, Pd. T-19-2005B, Pedoman Studi Kelayakan Proyek Jalan dan Jembatan, Jakarta, 2005

Direktorat Jenderal Bina Marga, Tata Cara Perencanaan Geometrik Jalan Antar Kota, Departemen Pekerjaan Umum, Jakarta, 1997

Direktorat Jenderal Bina Marga dan Direktorat Jenderal Binkot, Manual Kapasitas Jalan Indonesia, Departemen Pekerjaan Umum, Jakarta, 1997

Donny M. M., Ekonomi Rekayasa, Andi Offset, Yogyakarta, 2013

Giantman M., Ekonomi Teknik, Rajawali Pers, Jakarta, 2011

Iman S., Manajemen Proyek Dar Konseptual Sampai Operasional, Erlangga, Jakarta, 1997

Peraturan Pemerintah No 34 Tahun 2006 Tentang Jalan

Martin K., Kajian Kelayakan Ekonomi Pengembangan Jaringan Jalan Ke Lokasi Obyek Wisata Di Kabupaten Kerinci Propinsi Jambi, Tesis, Program Magister Teknik Sipil Konsentrasi Pengelolaan Jaringan Jalan Kerja Sama Pusat Pembinaan Keahlian Dan Teknik Konstruksi Departemen Pekerjaan Umum Dengan Program Pascasarjana Universitas Katolik Parahyangan, Bandung, 2008

Pusat Penelitian dan Pengembangan Jalan dan Jembatan, Evaluasi Ekonomi Pembangunan Jalan, Rancangan Pedoman, Badan Penelitian dan 
Pengembangan Departemen Pekerjaan

Umum, Bandung, 2005

Silvia S., Perkerasan Lentur Jalan Raya, Nova, Bandung, 2010

Tamin O. Z., Perencanaan Pemodelan dan Rekayasa Transportasi, ITB Pres, Bandung, 2008

Undang-Undang No 38 Tahun 2004 Tentang Jalan 